\title{
SEDIMENTÁRNĚ-GEOLOGICKÉ STUDIUM VYBRANÝCH KVARTÉRNÍCH SEDIMENTŮ V OKOLÍ BRNĚNSKÉ PŘEHRADY
}

\author{
Sedimentological study of the selected Quaternary deposits in the area of the Brno dam \\ Marek Mikulík', Slavomír Nehyba', František Hubatka² \\ ' Ústav geologických věd PřF MU, Kotlářská 2, 61137 Brno; e-mail: 175886@mail.muni.cz \\ ${ }^{2}$ Kolej Consult \& servis s. r. o., Křenová 35, 60200 Brno
}

(24-32 Brno)

Key words: fluvial deposits, lithofacies, Pleistocene

\begin{abstract}
Outcrops of Quaternary deposits are lining banks of the Brno dam. One of them is situated on the left bank $\sim 250 \mathrm{~m} N \mathrm{~N}$ of the Osada pier. The sedimentary profile of Pleistocene deposits is composed of fluvial deposits of the Paleo - Svratka River covered by colluvial and eolian (loess) deposits. Alternation of various facies and various grain-size fractions reveals alternation of more or less arid conditions and also evolution of the surrounding landscape.
\end{abstract}

\section{Úvod}

Pro studium kvartérního vývoje krajiny jsou v našich podmínkách zajímavé zvláště různě mocné akumulace zejména fluviálních a eolických sedimentů v sepětí s morfologií jejich těles ve vazbě na vývoj okolního reliéfu. Rozsáhlým fluviálním akumulacím označeným jako říční terasy věnovali $\mathrm{v}$ brněnském prostoru pozornost např. Ř́kovský (1932a, 1932b), Zapletal (1927-1928), Musil 1982, Čurda et al. (1994), Müller et al. (2000) a mnozí další. Fluviální sedimenty spojované s řekou Svratkou se mimo jiné nachází v prostoru Brněnské přehrady, kde proběhla předložená studie.

Studovaná lokalita je situována na levém břehu brněnské přehrady cca $250 \mathrm{~m}$ sz. od zastávky Osada (obr. 1). Báze profilu leží ve výšce $233,5 \mathrm{~m} \mathrm{n}$. m. GPS souřadnice jsou $49^{\circ} 14^{\prime} 44.9^{\prime \prime} \mathrm{N}, 16^{\circ} 30^{\prime} 13.5^{\prime \prime} \mathrm{E}$. Stěna profilu je vysoká cca $4,5 \mathrm{~m}$ a dlouhá cca $20 \mathrm{~m}$. Orientace výchozu je SZ-JV.

\section{Metodika}

V rámci sedimentárního profilu (obr. 2) bylo vyčleněno 5 litofacií (faciální analýza Nemec 2005, Miall 1996) a odebráno celkem 6 vzorků pro zrnitostní analýzu. Ke studiu zajištěných vzorků byl použit vibrační sítovací př́stroj zn. Retsch AS 200 (frakce 0,063-4,00 mm, sítování za mokra) v kombinaci s laserovým granulometrem Cilas 1064 (frakce 0,04-500 $\mu \mathrm{m}$ ). Statické parametry zrnitosti sedimentů byly počítány dle vzorců Folk \& Ward 1957, klasifikace sedimentů dle Konty 1973.
Petrografickému studiu hrubé zrnitostní frakce (tj. nad $4 \mathrm{~mm}$ ) bylo podrobeno celkem 917 klastů [zaoblení zrn dle Powers (1953), tvar zrn dle tvarových tříd Zinggovi klasifikace (1935)]. Součástí studia sedimentů bylo měření objemové magnetické susceptibility. Měrení proběhlo za pomocí kappa můstku KLY-4. Vzorky byly upraveny do válečku cca ø $25 \times 22 \mathrm{~mm}$. Jedno měření probíhalo cca 25 sekund. Bylo realizováno celkem 158 měření na 32 vzorcích, odebraných vždy po $0,1 \mathrm{~m}$ ze začištěné stěny profilu. Měření, které vykazovalo výrazné odchylky, bylo opakováno natáčením vzorku ve snímací cívce (až 10 měření). Běžně však postačila pouze 3 měření. Získaná data byla přepočítána na hmotnostně - specifickou susceptibilitu ( $\chi$ ) vyjádřenou $\mathrm{v} \mathrm{m}^{3} \cdot \mathrm{kg}^{-1}$.

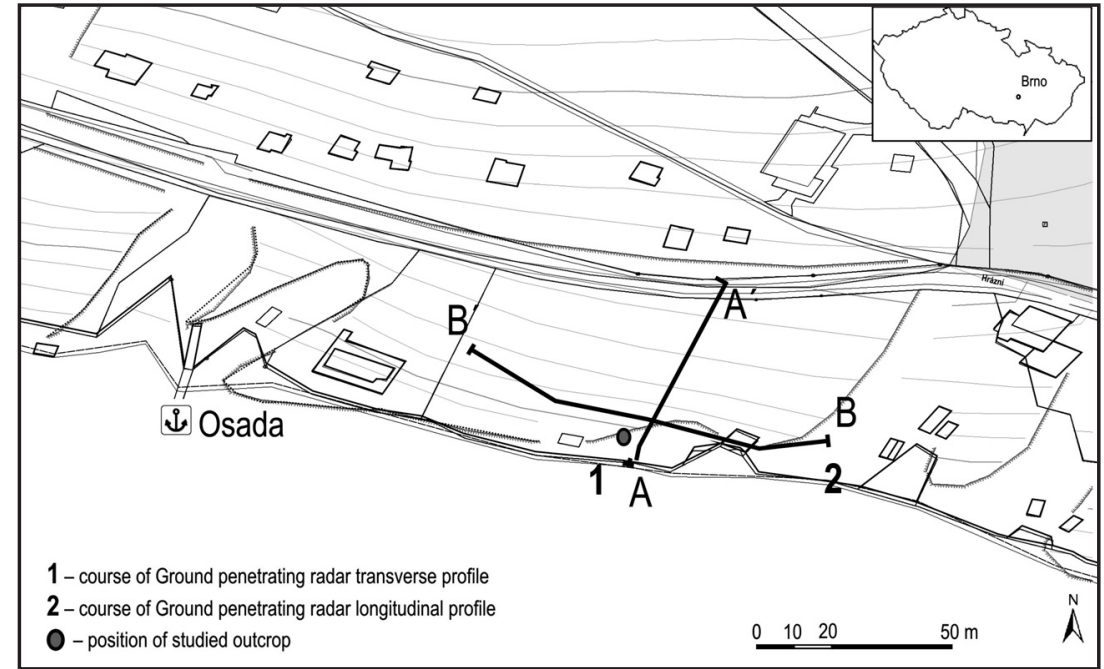

Obr. 1: Schematická pozice studovaného výchozu a průběh georadarových řezů.

Fig. 1: Schematic position of studied outcrop and the courses of Ground penetrating radar profiles. 


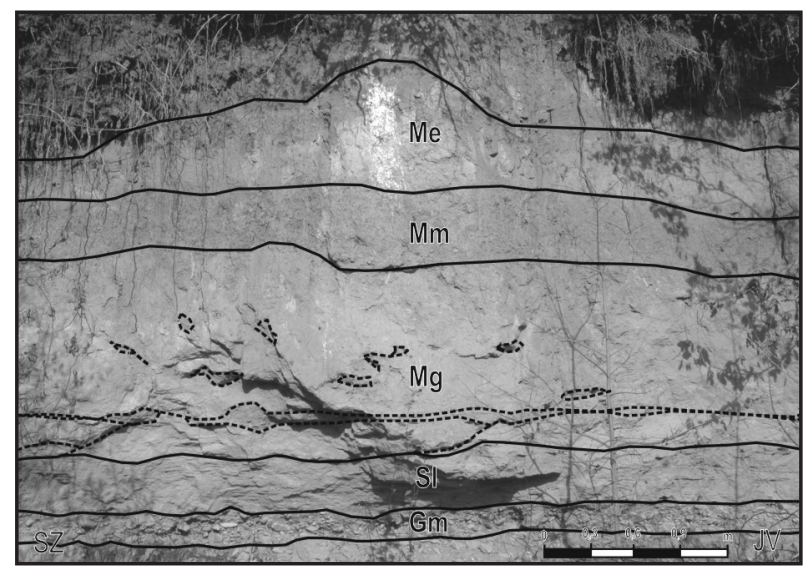

Obr. 2: Faciální architektura zájmového výchozu.

Fig. 2: Facies architecture of the studied outcrop.

Dva georadarové profily s využitím geofyzikálního radaru Pulse Ekko Pro při frekvenci $50 \mathrm{MHz}$, rozestupem antén $3 \mathrm{~m}$ a krokem měření $0,5 \mathrm{~m}$ byly na lokalitě provedeny za účelem bližšího poznání tvaru sedimentárních těles a charakteru podloží. $Z$ důvodu interpretace naměřených profilů byla provedena také jedna sonda vertikálního elektrického sondování VES.

\section{Výsledky a jejich interpretace}

Při bázi profilu vystupuje těleso hrubozrnného štěrku s podpůrnou strukturou valounů až písčité matrix. Maximální velikost klastů byla $25 \mathrm{~cm}$ (osa A), běžně však kolem $10 \mathrm{~cm}$. Svrchní hranice tělesa štěrku je nerovná. $\mathrm{V}$ rámci tělesa lze identifikovat hrubé planární zvrstvení a sediment přiřadit $\mathrm{k}$ facii $\mathrm{Gm}$ (Miall 1996). Byla pozorována přednostní orientace valounů a(p) a(i) i a(t) b(i), v rozmezí od $284^{\circ}-324^{\circ}$ (12 měření). Valounová analýza (frakce nad $8 \mathrm{~mm}, 376$ klastů) ukazuje na značné zastoupení rul (38,6\%). Běžné jsou hlavně středně zrnité muskovitické, dvojslídné, načervenalé (růžové) až světle šedé typy (s dobře vyvinutou foliací) s převážně diskovitým $(44,3 \%)$ nebo čepelovitým (34,2\%) tvarem. Tvary sloupcovitý $(17,4 \%)$ a sférický $(5,1 \%)$ jsou méně zastoupeny. Valouny rul byly většinou polozaoblené $(47,4 \%)$ a zaoblené $(35,5 \%)$ nebo poloostrohranné (16,8\%). Hojné zastoupení vykazují také bělavé až světle šedé, místy načervenalé valouny křemene (23,1\%), které mají nejčastěji diskové, sférické a vřetenovité tvary, méně často pak tvary čepelovité. Valouny křemene byly zejména poloostrohranné $(48,9 \%)$ nebo polozaoblené (36,4 \%). Ze sedimentárních hornin byly zastiženy jemnozrnné až středozrnné, šedé, světle až rezavě hnědé pískovce $(16,8 \%)$, které jsou obvykle zaoblené, výjimečně polozaoblené. $V$ malém množství (první procenta) byly zastiženy jemnozrnné křemenné pískovce a stř̌edozrnné arkózy. Tyto mají především diskovité, čepelovité nebo vřetenovité (jednotlivě do $28 \%$ ) tvary, méně pak tvary sférické a jsou dobře až velmi dobře zaoblené (79,9\%) nebo polozaoblené $(20,1 \%)$. $Z$ dalších hornin byly zastiženy zaoblené převážně diskovité či čepelovité valouny svoru (11,7\%), metabazitu $(2,1 \%)$, křemen - živcového agregátu (1,6\%), amfibolitu (1,1\%), dioritu (1,1\%), granitoidů $(0,9 \%)$ a tmavě hnědého až světle černého rohovce $(0,6 \%)$. Facie $\mathrm{Gm}$ je interpretována jako produkt fluviální sedimentace, spojovaný především s tvorbou říčních (vnitrokorytových?) valů. Tyto sedimenty zařazují (Müller et al. 2000) do období spodního a začátku středního pleistocénu (günz - mindel) mezi tuřanskou a rebešovickou terasu. V pojetí Zapletala (1927-1928) se jedná o říční terasu B (30 m nad hladinou řeky) a dle Ř́kovského (1932a) o úroveň I/1 (20 m). V geologické mapě (Cícha et. al 1967) jsou tyto sedimenty zakresleny jako fluviální štěrkopísky mladšího mindelu (rebešovická terasa). Pro valouny je typická relativně vzdálenější zdrojová oblast, kde výraznou roli zaujímají ruly moravika a svrateckého krystalinika. Určitou roli hrály také sedimenty boskovické brázdy a nejspíše i starší fluviální sedimenty stárí ottnang známé v okolí.

V nadloží štěrku se vyskytuje středně zrnitý až jemnozrnný písek střídající se $s$ mírně zvlněnými laminami šedohnědého siltu, př́padně až světle žlutohnědý, jemně slídnatý až jemnozrnný písek s občasnou prítomností valounků do $3 \mathrm{~cm}$. Mocnost vrstvy nepřesahuje $0,45 \mathrm{~m}$ a její strop i báze jsou nerovné. Granulometrické studium ukázalo dominanci prachové (49\%) a písčité frakce (48\%), podružně pak frakce jílové $(2 \%)$ a štěrkové $(1 \%)$. Sediment vykazoval špatné vytřídění, přičemž hodnota koeficientu oI odpovídala 1,9 $\Phi$ (Folk \& Ward 1957). Medián Mz dosahoval hodnoty 4,45 $\Phi(0,044 \mathrm{~mm})$. Sediment lze spojit s facií Sl (Miall 1996). Př̀i svrchní hranici tohoto tělesa byly vzácně zjištěny izolované až $30 \mathrm{~cm}$ velké poloostrohranné klasty granodioritu. Tyto sedimenty spojujeme jednak s fluviální činností, kdy se nejspíše jedná o průvalové sedimenty usazené již mimo paleokoryto. Př́tomnost málo opracovaných klastů tvořených horninami nejbližšího okolí (tj. brněnského masivu) spojuje jejich původ s činností gravitace a ukazuje na existenci výrazného ukloněného reliéfu se slabě zvětralými odkryvy granitoidů $v$ době sedimentace.

Výše v nadloží vystupuje komplex (mocný až $1,4 \mathrm{~m}$ ) světle šedých, světle hnědých, zrzavě šmouhovaných vápnitých písčitých siltů se šikmou až mírně zvlněnou laminací, ve kterých vystupují občasná nepravidelně klínovitá až čočkovitá tělesa štěrkovitého písku s ostrohrannými klasty (max. osa A do $1 \mathrm{~cm}$ ), př́padně ve vyšších partiích jednotlivé roztroušené klasty s délkou osy $\mathrm{A}$ až do $0,7 \mathrm{~cm}$ (facie Mg). Komplex je charakteristický nerovnou bází i stropem. Pro laminované písčité silty (2 zrnitostní analýzy) je charakteristická dominance prachové frakce (60-68 \%), frakce písčitá (jemnozrnný a velmi jemnozrnný písek) představuje 28-31,5\% a př́tomnost jílové složky je velmi malá $(<3 \%)$. Koeficient vytř́dění $\sigma \mathrm{I}$ se pohyboval v hodnotách 1,9-3,0 $\Phi$. Medián Mz dosahoval hodnot 4,4 až 5,1 $\Phi(0,03$ až $0.053 \mathrm{~mm})$. Tělesa štěrkovitého písku mají velmi nepravidelný tvar i mocnost (vzácně až $15 \mathrm{~cm}$ ), nepravidelná je také jejich báze i strop. Zřetelná je dominance písčité frakce (57\%) a významný podíl frakce štěrkové (31\%). Prachová komponenta představuje $11,5 \%$ a jílová pouze do $0,5 \%$. Štěrkovitý písek byl špatně vytř́íděný (koeficient $\sigma \mathrm{I}$ je roven $2,5 \Phi$ ) a medián Mz dosahoval hodnoty $-0,59 \Phi(1,47 \mathrm{~mm})$. U facie Mg lze uvažovat o eolicko-koluviální sedimentaci. Šmouhované písčité silty můžeme spojit s usazováním ze vzdušné masy 
a nepravidelná tělesa s ostrohrannými klasty s kombinací gravitačních a fluviálních procesủ. Tyto procesy lze spojit se stř́́dáním relativně chladnějších a sušších období $\mathrm{s}$ obdobími relativně teplejšími s fluviálně-aluviálními splachy především ostrohranných zvětralin nejbližšího okolí a podřizeně také starších sedimentů. Během této fáze sedimentace docházelo k postupnému zarovnávání reliéfu.

V nadloží vystupuje facie Mm tvořená sytě hnědým zahliněným písčitým siltem s hojnou přítomností angulárních až subangulárních klastů růžového až načervenalého granitu až granodioritu (max. do $0,5 \mathrm{~cm}$, osa $\mathrm{A}$ ) a občasným výskytem zaoblených až polozaoblených valounů (do $5 \mathrm{~cm}$ ). Ostrohranné klasty jsou prítomny zejména na bázi a díky ubývání jejich př́tomnosti směrem vzhůru vykazuje facie pozitivní gradaci. Dále jsou typické časté stopy po kořenech a projevy pedogeneze. Mocnost tělesa je proměnlivá, nepřesahuje však $0,85 \mathrm{~m}$. Granulometrické studium ukázalo dominanci prachové komponenty (66\%) a významný podíl písčité frakce (29\%). Jílová frakce představuje $2 \%$, štěrková frakce je reprezentována $3 \%$. Písčitý silt vykazoval špatné vytř́íění (koeficient $\sigma \mathrm{I}$ je roven 3,49 Ф). Medián Mz odpovídal hodnotě 4,45 $\Phi(0,048 \mathrm{~mm})$.

Nejvyšší část profilu představuje světle žlutohnědý masivní vápnitý písčitý silt (facie $\mathrm{Me}$ ) se stopami po kořenech. Mocnost tělesa je do $0,8 \mathrm{~m}$. Facie je charakteristická vysokým zastoupením prachové frakce (79\%) a absencí štěrkové složky. Písčitá složka je reprezentována $17 \%$ a jílovitá složka $4 \%$. Sediment vykazoval špatné vytřídění, přičemž hodnota koeficientu oI odpovídala 2,1 $\Phi$ (Folk \& Ward 1957). Medián Mz dosahoval 5,9 Ф (0,018 mm). Facie Me představuje produkt eolické sedimentace a lze ji označit za sprašový sediment.

Petrografické složení hrubé zrnitostní frakce (tj. nad $4 \mathrm{~mm}$ ) zjištěné $\mathrm{v}$ rámci facie $\mathrm{Sl}$ (72 klastů) i nadložních facií Mg (331 klastů) a Mm (138 klastů) je vcelku jednotné. Typická je dominance angulárních až subangulárních zrn křemene (40-50\%) a červeného až růžového granitu až granodioritu (35-42\%). Nejčastější jsou tvary sférické a diskovité, méně pak vřetenovité. $Z$ dalších hornin byly podřadně zastoupeny křemen-živcový agregát, jemnozrnný vápenec, rula, svor, metabazit a pískovce. Tyto klasty mají obvykle diskovitý či vřetenovitý tvar a jsou především polozaoblené (pískovce, svor) až subangulární (křemen-živcový agregát).

Magnetická susceptibilita (MS) byla vyhodnocena celkem u 32 vzorků z facií Gm, Sl, Mg, Mm i Me. Měřené hodnoty se pohybovaly v rozmezí od $0,419 \times 10^{-6}$ do $1,905 \times 10^{-6} \mathrm{~m}^{3} \cdot \mathrm{kg}^{-1}$. Nejvyšších hodnot MS bylo dosaženo ve facii $\mathrm{Gm}$ (v rámci písčité až písčito-štěrkovité matrix hrubozrnného štěrku) cca $0,1 \mathrm{~m}$ nad úrovní báze studovaného profilu $\left(1,905 \times 10^{-6} \mathrm{~m}^{3} \cdot \mathrm{kg}^{-1}\right)$, zatímco nejnižších hodnot dosahovaly vápnité písčité silty cca $0,2 \mathrm{~m}$

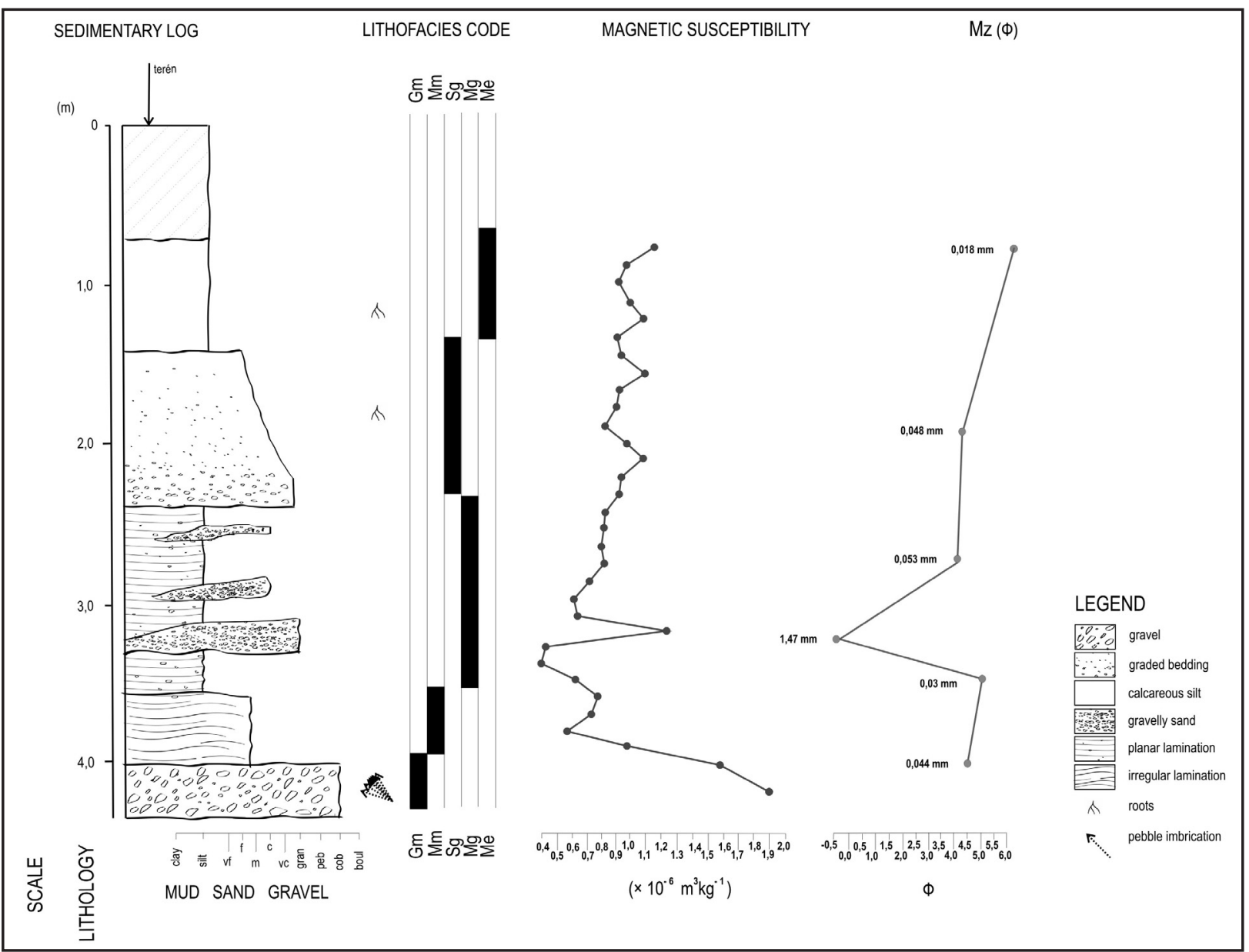

Obr. 3: Litologický profil, hodnoty magnetické susceptibility a střední velikosti zrna (Mz).

Fig. 3: Lithology, values of magnetic susceptibility and mean grain size $(\mathrm{Mz})$ of the studied profile. 
nad bází facie $\mathrm{Mg}\left(0,418 \times 10^{-6} \mathrm{~m}^{3} \cdot \mathrm{kg}^{-1}\right)$.V rámci sedimentárního profilu (tj. od 1,1 m nad úrovní báze profilu) lze již pozorovat relativně konstantní nárůst MS směrem do nadloží. Výjimku zde tvoří hodnota dosažená ve facii $\mathrm{Mg}$, kde těleso štěrkovitých písků představuje nárůst MS. MS pro jemnozrnnější frakce (písčité silty) se pohybuje mezi hodnotami 0,418 až $1,15 \times 10^{-6} \mathrm{~m}^{3} \cdot \mathrm{kg}^{-1}$, kdežto hrubozrnnější frakce (štěrkovitý písek) kopírují vyšší hodnoty MS. Dosažené výsledky jsou znázorněny na obr. 3.

$\mathrm{V}$ příčném georadarovém řezu (obr. 4) se nezvětralé skalní podloží nachází v hloubce 8 až $18 \mathrm{~m}$ (těleso 1 ). V nadloží je vyvinuto velmi nepravidelné těleso nejspíše zvětralin o mocnosti až $10 \mathrm{~m}$ (těleso 2). Lze pozorovat nepravidelný úklon skalního podloží generelně k JZ. Tato tělesa nevystupují v nejbližším okolí studovaného území na povrch. Velmi nápadné je seříznutí svrchní části tělesa zvětralin v protažení erozního klifu na březích dnešního přehradního jezera. Nadloží tělesa zvětralin je odlišné $\mathrm{v}$ místech pod hladinou údolní nádrže a v rámci jejích břehů (to zčásti ukazuje na genezi nadložních sedimentů). $\mathrm{V}$ místech břehu nacházíme $\mathrm{v}$ př́mém nadloží tělesa 2 několik sedimentárních poloh s ukloněnými (agradačními) a planárními vnitřními reflexy, které označujeme jako těleso I. Tyto sedimenty lze interpretovat jako fluviální, spojit je nejspíše s faciemi Gm a Sl studovanými v rámci břežního klifu. Fluviální sedimenty tedy zasahují asi kolem
30 m od okraje abrazního klifu směrem k SV. Těleso II v nadloží je tvořeno řadou drobnějších poloh, které mají nepravidelně protáhlou korytovitou bázi, masivnější charakter reflexů často rovnoběžných s bází poloh. Sedimenty tohoto tělesa lze spojit s faciemi $\mathrm{Mg}, \mathrm{Mm}$ a $\mathrm{Me}$ a jejich deluviálně-eolickým charakterem. Nejvyšší část profilu je pak tvořena subhorizontálně uloženým tělesem III s detailnějšími reflexy rovnoběžnými se subhorizontální bází tělesa. Tyto sedimenty odpovídají půdní vrstvě. V oblasti pod hladinou jezera jsou v nadloží zvětralinového pláště hornin brněnského masivu (těleso 2) vyvinuty sedimenty s nepravidelnou bází a relativně masivními reflexy ukloněnými směrem k JZ (těleso IV). Charakter reflexů je relativně podobný situaci v rámci výše popsaného tělesa II. Tyto sedimenty proto spojujeme s řícením břehů přehradního jezera ve spojení s břežní nátrží a následnou akumulací (spolu s částečným rozplavením) podél okraje přehrady při počátečních stadiích formování břežního pásma přehradního jezera. V nadloží tělesa IV leží sedimenty tělesa V. Můžeme pozorovat horizontální bázi, deskovitý tvar a vcelku rovnoběžný průběh relativně detailních vnitřních reflexů. Sedimenty lze spojit jednak se sedimentací v břežní zóně přehradního jezera i s usazením především pod hladinou vody.

V podélném řezu (obr. 5) se povrch skalního podloží nachází v hloubce 5 až $7 \mathrm{~m}$. Nápadný je skok v hloubce pře-

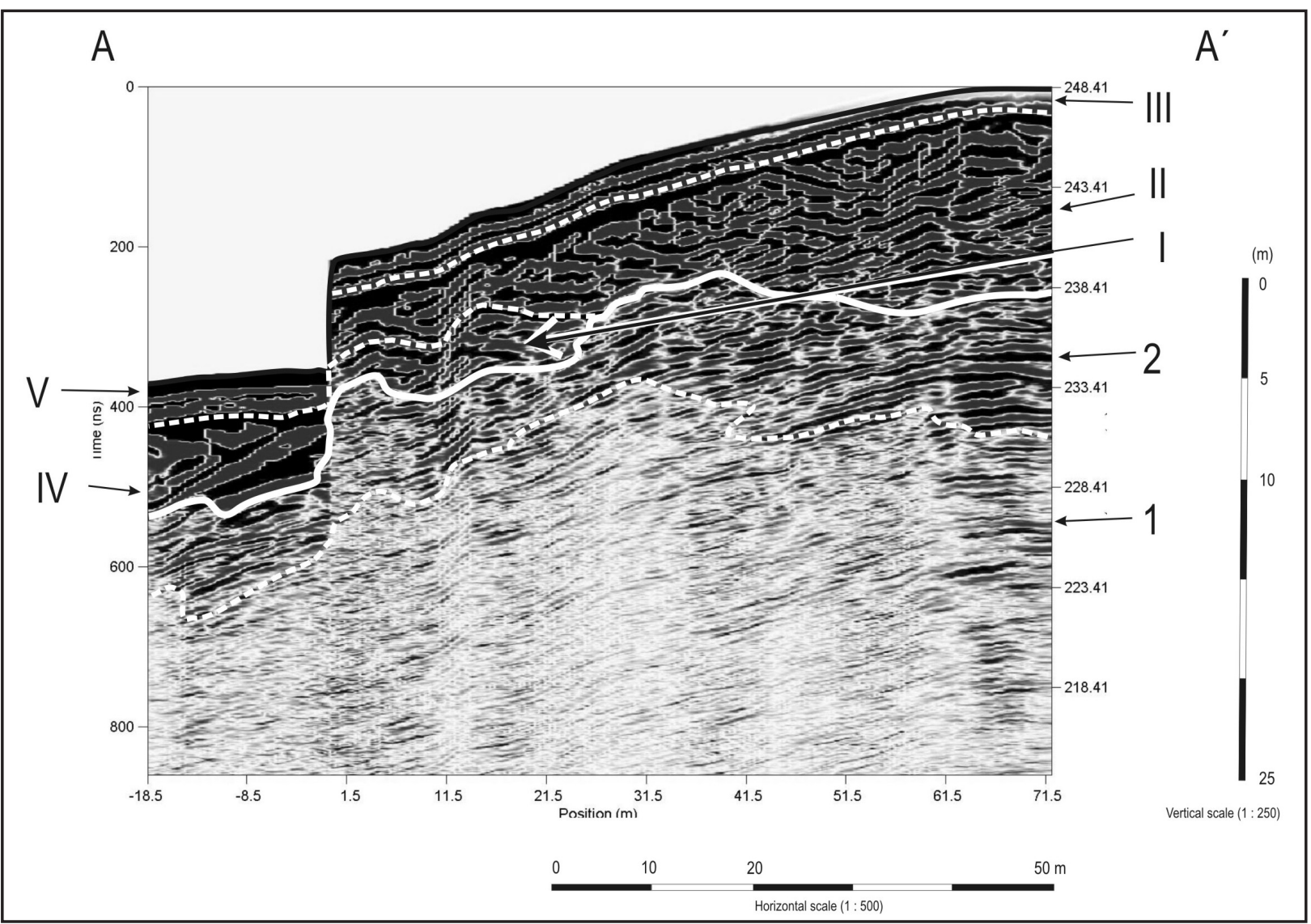

Obr. 4: Příčný georadarový profil. Legenda: 1 - nezvětralé skalní podloží; 2 - zvětralinový plášṫ; I - fluviální sedimenty; II - koluviálněeolické sedimenty; III - půdní kryt; IV - sedimenty spojené s řícením břehů přehradního jezera; V - sedimenty přehradního jezera. Fig. 4: Ground penetrating radar transverse profile. Explanation: 1 - solid rocks of Brno Massif; 2 - weathered rocks of Brno Massif; I - Quaternary fluvial deposits; II - Quaternary colluvial and eolian deposits; III - soils; IV - collapsed parts of the bank cliff; $\mathrm{V}$ - modern deposits of the Brno reservoir. 


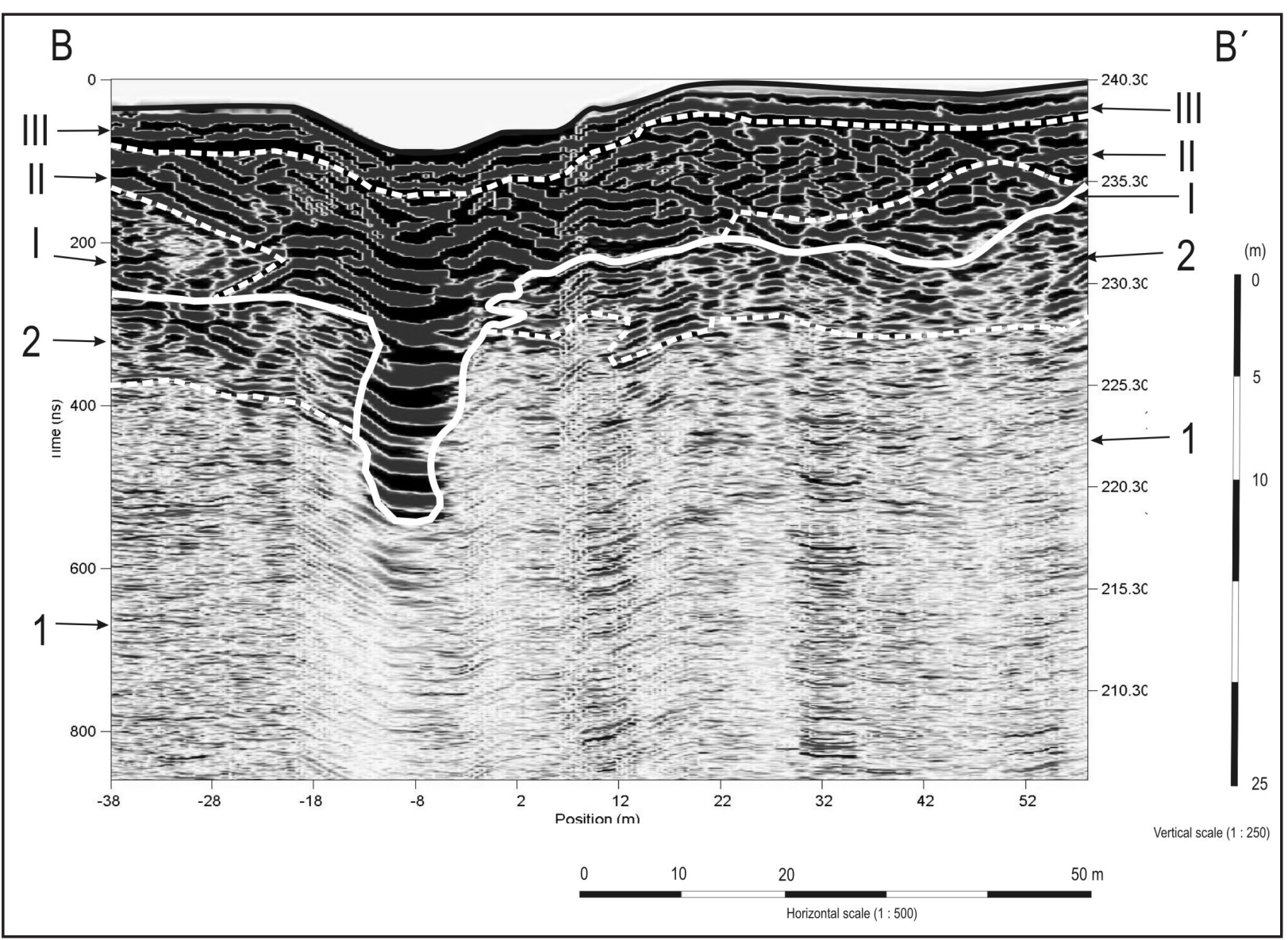

Obr. 5: Podélný georadarový profil. Legenda: 1 - nezvětralé skalní podloží; 2 - zvětralinový plášt; I - fluviální sedimenty; II koluviálně-eolické sedimenty; III - půdní kryt.

Fig. 5: Ground penetrating radar longitudinal profile. Explanation: 1 - solid rocks of Brno Massif; 2 - weathered rocks of Brno Massif; I - Quaternary fluvial deposits; II - Quaternary colluvial and eolian deposits; III - soils.

devším nezvětralého skalního podloží odpovídající poloze erozní rýhy (v protažení Rokle). To ukazuje na tektonickou predispozici tohoto erozního tvaru vzniklého především ronovou činností. Vpravo a vlevo od erozní rýhy můžeme pozorovat rozdílnou mocnost zvětralinového pláště, i jeho zvlněný povrch. V nadloží krystalinických hornin jsou dva izolované výskyty sedimentů tělesa I, které mají zvlněný průběh báze. Vnitřně lze odlišit kombinaci konvexního a konkávního průběhu reflexů. Sedimenty tělesa II nasedají někde na zvětralé skalní podloží, jinde kryjí sedimenty tělesa I. Polohy sedimentů tělesa II mají nepravidelnou protáhlou korytovitou bázi, masivnější charakter reflexů rovnoběžný s bází. Erozní rýha je vyplněna také těmito horizontálně uloženými sedimenty, které zde vykazují subhorizontální průběh reflexů. Vyšší partie tělesa II, zvláště při okrajích erozní rýhy a tam, kde kryjí podložní sedimenty, mají ukloněný průběh. Nejvyšší část profilu pak tvoří generelně deskovité, $v$ místech erozní rýhy konvexně prohnuté, těleso III. Jeho báze má zvlněný charakter se zahloubením v místě erozní rýhy a reflexy jsou obecně horizontální, když kopírují průběh báze.

Pleistocenní fluviální sedimenty tedy sedimentovaly v zájmovém prostoru přímo na horniny brněnského masivu. Starší neogenní sedimenty (známé z blízkého okolí) byly ze zájmového prostoru v rozhodující míre vyklizeny před jejich usazením. Relativně výrazný reliéf byl následně (tj. po usazení fluviálních sedimentů) částečně zarovnán především díky koluviálně-eolické sedimentaci. $V$ rámci málo odolných koluviálně-eolických sedimentů vznikaly erozní rýhy, které byly ve spodních partiích vyplňovány výše ve svahu erodovaným materiálem.

\section{Poděkování}

Studium bylo částečně podpořeno grantem GA ČR 205/09/0103. 


\section{Literatura}

Cícha, I. et al. (1969): Základní geologická mapa 1: 25 000, list M-33-106-A-c (Brno-západ). - Ústřední ústav geologický Praha.

Čurda, J. et al. (1994): Vysvětlivky k souboru geologických a ekologických účelových map př́rodních zdrojů, list 24-32 Brno. Český geologický ústav Praha.

Folk, R. L. - Ward, W. (1957): Brazos River bar: a study in the significance of grain-size parameters. - Journal of Sedimentary Petrology, 27, 3-26.

Konta J. (1973): Kvantitativní systém reziduálních hornin, sedimentů a vulkanoklastických usazenin. - Petrografický ústav UK Praha.

Miall, A. D. (1996): The geology of fluvial deposits. - Springer-Verlag, 1-582. Berlin.

Müller, P. - Novák, Z. - Bubík, M. - Buriánková, K. - Čurda, J. - Eliáš, M. - Gilíková, H. - Gregerová, M. - Grym, V. - Hanák, J. - Hanžl, P. - Havlíček, P. - Hrádek, M. - Kadlec, J. - Krejčí, O. - Květoňová, E. - Melichar, R. - Müller, V. - Müllerová, H. - Novák, M. - Otava, J. - Pálenský, P. - Petrová, P. - Píše, J. - Sedlák, J. - Šmerdová, B. - Valoch, K. - Vít, J. (2000): Geologie Brna a okolí. - Český geologický ústav Brno.

Musil, R. ed. (1982): Kvartér brněnské kotliny - Stránská skála IV. - Studia geographica, 80, 1-283. Brno.

Nemec, W. (2005): Principles of lithostratigraphic logging and facies analyses. - Institutt for geovitenskap, Uni. Bergen, 1-28.

Powers, M. C. (1953): A new roundness scale of sedimentary particles. - Journal of Sedimentary Petrology, 23, 117-119.

Říkovský, F. (1932a): Fluviatilní terasy stř̌ední Svratky. - Spisy vydávané Př́rodovědeckou fakultou Masarykovy university, 152, 1-22. Brno.

Říkovský, F. (1932b): Předmiocenní reliéf a miocenní plošiny v oblasti střední Svratky. -Spisy vydávané Přírodovědeckou fakultou Masarykovy university, 149, 1-21. Brno.

Zapletal, K. (1927-1928): Geologie a petrologie okolí brněnského. - Časopis Moravského zemského musea, XXV, 67-111.

Zingg, T. (1935): Beitrag zur Schotteranalyse, Schweizerische Mineralogische Petrogische Mitteilungen, 15, 39-140. 